\title{
Oocyte-derived growth factors and ovulation rate in sheep
}

\author{
K. P. McNatty ${ }^{1}$, J. L. Juengel ${ }^{1}$, T. Wilson ${ }^{2}$, S. M. Galloway ${ }^{2}$, \\ G. H. Davis ${ }^{3}$, N. L. Hudson ${ }^{1}$, C. L. Moeller ${ }^{4}$, M. Cranfield ${ }^{5}$, \\ K. L. Reader ${ }^{1}$, M. P. E. Laitinen ${ }^{6}$, N. P. Groome ${ }^{5}$, \\ H. R. Sawyer ${ }^{4}$ and O. Ritvos ${ }^{6}$
}

${ }^{7}$ AgResearch, Wallaceville Animal Research Centre, PO Box 40063, Upper Hutt, New Zealand; ${ }^{2}$ AgResearch, Molecular Biology Unit, Department of Biochemistry, University of Otago, PO Box 56, Dunedin, New Zealand; ${ }^{3}$ AgResearch, Invermay Agricultural Centre, Private Bag 50034, Mosgiel, Dunedin, New Zealand; ${ }^{4}$ Department of Biomedical Sciences, Animal Reproduction and Biotechnology Laboratory, Colorado State University, Fort Collins, CO 80523-1683, USA; ${ }^{5}$ School of Biological and Medical Sciences, Oxford Brookes University, Gypsy Lane Campus, Headington, Oxford, UK; and ${ }^{6}$ Programme for Developmental and Reproductive Biology, Biomedicum Helsinki and Department of Bacteriology and Immunology, Haartman Institute, 00014 University of Helsinki, Helsinki, Finland

The physiological mechanisms controlling ovulation rate in mammals involve a complex exchange of endocrine signals between the pituitary gland and the ovary, and a localized exchange of intraovarian hormones between the oocyte and its adjacent somatic cells. The discoveries in sheep of mutations in bone morphogenetic protein 15 (BMP15) and bone morphogenetic protein receptor type IB (BMPR-IB) together with recent findings on the physiological effects of growth differentiation factor 9 (GDF9) and BMP15 on follicular development and ovulation rate highlight some important differences in the way in which the oocyte may function in mammals with different ovulation rate phenotypes. In sheep, BMP15 and GDF9 have each been shown to be essential for the early and later stages of follicular development. In addition, ovulation rate is sensitive to changes in the dose of either of these two oocyte-derived growth factors. These findings are in contrast to those reported for mice in which GDF9, but not BMP15, is essential for follicular development. The evidence to date is consistent with the hypothesis that the oocyte plays a central role in regulating key events in the process of follicular development and hence, is important in determining ovulation rate. Moreover, it appears that the mechanisms that the oocyte uses to control these processes differ between species with low and high ovulation rate phenotypes. 


\section{Introduction}

Humans, cattle, goats and sheep typically have an ovulation rate of one or two $_{t}$ whereas other mammals, such as rats, mice, dogs and pigs have ovulation rates of four or more. Thus, when asking fundamental questions as to why some individual domestic livestock species, or indeed humans, have a predisposition to produce two or three offspring rather than one, it is useful to study experimental animal models with a low ovulation rate phenotype. In this context, sheep are proving to be remarkably informative experimental models (McNatty et al., 2001; Montgomery et al., 2001).

Control of ovulation rate in mammals not only involves a complex exchange of hormonal signals between the pituitary gland and the ovary, but also is dependent on local communication, via intraovarian hormones and growth factors between oocytes and their adjacent somatic cells. (Scaramuzzi et al., 1993; Baird and Campbell, 1998; McNatty et al., 1999; Galloway et al., 2000; Eppig, 2001; Juengel et al., 2002). The temporal interrelationships between the pituitary hormones, $\mathrm{FSH}$ and $\mathrm{LH}$, and the ovarian hormones, oestradiol, progesterone and inhibin, are reasonably well understood. Administration of supplementary FSH to predominantly mono-ovulatory species, such as humans, cattle and sheep, can over-ride the endogenous control mechanisms that govern ovulation rate and stimulate multiple ovulations (that is, $\geqslant 4$ ). In addition, small temporal changes in plasma FSH concentrations around the time of luteal regression appear to be the physiological basis that explains why some sheep ovulate two or three eggs rather than one (MCNatty et al., 1985, 1988; Henderson et al., 1988). Although higher than normal FSH concentrations may explain, in part, why some Booroola ewes have exceptionally high ovulation rates (between 8 and 13; Hudson et al, 1999), it is important to emphasize that changes in plasma FSH concentrations alone do not explain all the observed differences in ovulation rate among breeds of sheep (Driancourt et al., 1988; Shackell et al., 1993; Fry and Driancourt, 1996) or indeed why some species always ovulate several follicles and others mainly one. Results from studies with mice lacking certain growth factor genes or sheep with naturally occurring genetic mutations in certain oocyte-derived growth factors provide evidence that the oocyte plays an essential role not only in regulating the growth and maturation of ovarian follicles, but also in determining ovulation rate (Dong et al., 1996; Galloway et al., 2000). As the oocyte has such a major effect on follicular growth and ovulation rate, it is reasonable to hypothesize that the relative importance, and indeed actions, of certain oocyte-derived growth factors may vary between mammals with different ovulation rate phenotypes.

The purpose of this review is to summarize recent findings on single genetic mutations that affect ovulation rate in sheep. Moreover, these data, together with new evidence from physiological studies, are presented to support the hypothesis that follicular growth and ovulation rate are influenced, in a dose-dependent manner, by oocyte-derived growth factors that influence somatic cells of the ovarian follicle and that the importance of these growth factors differs between mammals with a low or high ovulation rate phenotype.

\section{Sheep with single genetic mutations affecting ovulation rate}

The inheritance patterns of several naturally occurring genetic mutations that cause anovulation or either modest $(0.2-0.4)$ or large $(\geqslant 0.8)$ increases in ovulation rate in sheep have been identified (McNatty et al., 2001; Davis et al., 2002). In several of these sheep families, namely, Inverdale $(\mathrm{FeCX})$, Hanna $\left(\mathrm{Fec} \mathrm{X}^{\mathrm{H}}\right)$, Booroola $\left(\mathrm{FecB}^{\mathrm{B}}\right)$, Garole $\left(\mathrm{FecB}^{\mathrm{B}}\right)$ and Javanese $\left(\mathrm{FecB}^{\mathrm{B}}\right)$, the inherited mutation has been mapped to a specific region of the sheep $\mathrm{X}$ chromosome (Inverdale, Hanna) or sheep chromosome 6 (Booroola, Garole and Javanese) (Table 1). 
Table 1. Mutations in an oocyte-derived growth factor or a growth factor receptor in different sheep families, and the effects of genotype on mean ovulation rate and litter size

\begin{tabular}{|c|c|c|c|c|}
\hline \multirow{2}{*}{$\begin{array}{l}\text { Gene identification } \\
\text { (Chromosome } \\
\text { number) }\end{array}$} & \multirow{2}{*}{$\begin{array}{l}\text { Sheep family } \\
\text { (Allele) }\end{array}$} & \multicolumn{2}{|c|}{ Phenotype } & \multirow[b]{2}{*}{ Reference } \\
\hline & & (Ovulation rate) & (Litter size) & \\
\hline \multirow[t]{2}{*}{$\begin{array}{l}\text { BMP15 } \\
\text { (X) }\end{array}$} & $\begin{array}{l}\text { Inverdale } \\
\text { (Fec X') }\end{array}$ & $\begin{array}{c}++(1.8) \\
1+(2.9) \\
I I(0)\end{array}$ & $\begin{array}{c}++(1.6) \\
1+(2.3) \\
\text { II }(0)\end{array}$ & $\begin{array}{l}\text { Galloway et al. (2000) } \\
\text { Davis et al. (2001a) }\end{array}$ \\
\hline & $\begin{array}{l}\text { Hanna } \\
\left(\text { Fec } X^{H}\right)\end{array}$ & $\begin{array}{l}++(1.8) \\
H+(2.9) \\
H H(0)\end{array}$ & $\begin{array}{l}++(1.6) \\
H+(2.2) \\
H H(0)\end{array}$ & $\begin{array}{l}\text { Galloway et al. (2000) } \\
\text { Davis et al. (2001a) }\end{array}$ \\
\hline \multirow[t]{3}{*}{$\begin{array}{l}\text { BMPR-IB } \\
\text { (6) }\end{array}$} & $\begin{array}{l}\text { Booroola } \\
\left(\text { FecB }^{B}\right)\end{array}$ & $\begin{array}{l}++(1.5) \\
B+(2.8) \\
B B(4.6)\end{array}$ & $\begin{array}{l}++(1.3) \\
B+(2.2) \\
B B(2.7)\end{array}$ & $\begin{array}{l}\text { Wilson et al. (2001) } \\
\text { Mulsant et al. (2001) } \\
\text { Souza et al. (2001) } \\
\text { Davis et al. (1982) }\end{array}$ \\
\hline & $\begin{array}{l}\text { Garole } \\
\left(\mathrm{FecB}^{\mathrm{IS}}\right)\end{array}$ & Unknown & $\mathrm{BB}(2.2+)$ & Davis et al. (2002) \\
\hline & $\begin{array}{l}\text { Javanese } \\
\left(\text { Fec } B^{\beta}\right)\end{array}$ & $\begin{array}{c}++(1.4) \\
B+(2.7) \\
B B \text { (unknown) }\end{array}$ & $\begin{array}{l}++(1.2) \\
B+(1.9) \\
B B(2.6)\end{array}$ & Davis et al. (2002) \\
\hline
\end{tabular}

BMP15: bone morphogenetic protein 15; BMPR-IB; bone morphogenetic protein IB receptor.

In each of these animals, a point mutation was identified in genes from the transforming growth factor $\beta$ (TGF $\beta$ ) superfamily or their receptors (Table 1). In Inverdale and Hanna ewes, separate point mutations were identified in the bone morphogenetic protein 15 (BMP15) gene corresponding to sites in the mature peptide coding region of the BMP15 growth factor (also known as growth differentiation factor 9B; GDF9B) (Galloway et al, 2000). The ovine BMP15 mature protein consists of 125 amino acids. In Fec $X^{H}$ sheep, a single C to $T$ transition at nucleotide position 67 of the mature peptide coding region introduces a premature stop codon in the place of glutamic acid at amino acid residue 23 leading to a severe truncation and likely total loss of BMP15 bioactivity. In Fec $X^{\prime}$ ewes, a single T to A transition occurs at nucleotide position 92 of the mature peptide, thereby substituting a valine with aspartic acid at amino acid residue 31 of the mature protein. This mutation represents a non-conservative change in a highly conserved region of the protein and probably results in a marked reduction in BMP15 bioactivity in Fec $X^{\prime}$ ewes. Evidence to support this claim comes from phenotypic evaluation of the Hanna (H)-Inverdale (I) crossed ewe (HI). As with the homozygous Inverdale and Hanna ewes (Fig. 1), the $\mathrm{HI}$ animals are sterile (Galloway et al., 2000). A remarkable characteristic of Hanna or Inverdale ewes is that ewes that are heterozygous for the FecXH or FecXI mutation, have higher than normal ovulation rates and litter sizes (Davis et al., 2001a). Thus, for some reason, half the normal genetic dose of BMP15 leads to a higher than normal ovulation rate. No major effects of the $\mathrm{Fec} \mathrm{X}^{\mathrm{H}}$ or Fec $\mathrm{X}^{\prime}$ mutation are evident in males.

In Booroola, Garole and Javanese sheep, a point mutation was identified in the highly conserved intracellular serine threonine kinase signalling domain of the BMP-IB receptor (BMPR-IB) (Mulsant et al., 2001; Souza et al., 2001; Wilson et al., 2001; Davis et al., 2002). In $\mathrm{FecB}^{\mathrm{B}}$ sheep, a single $\mathrm{A}$ to $\mathrm{G}$ transition occurs at nucleotide position 830 , thereby substituting a glutamine (neutral/polar amino acid) for arginine (basic amino acid) at position 249 of the protein. This transition represents a non-conservative change in a highly conserved region of 

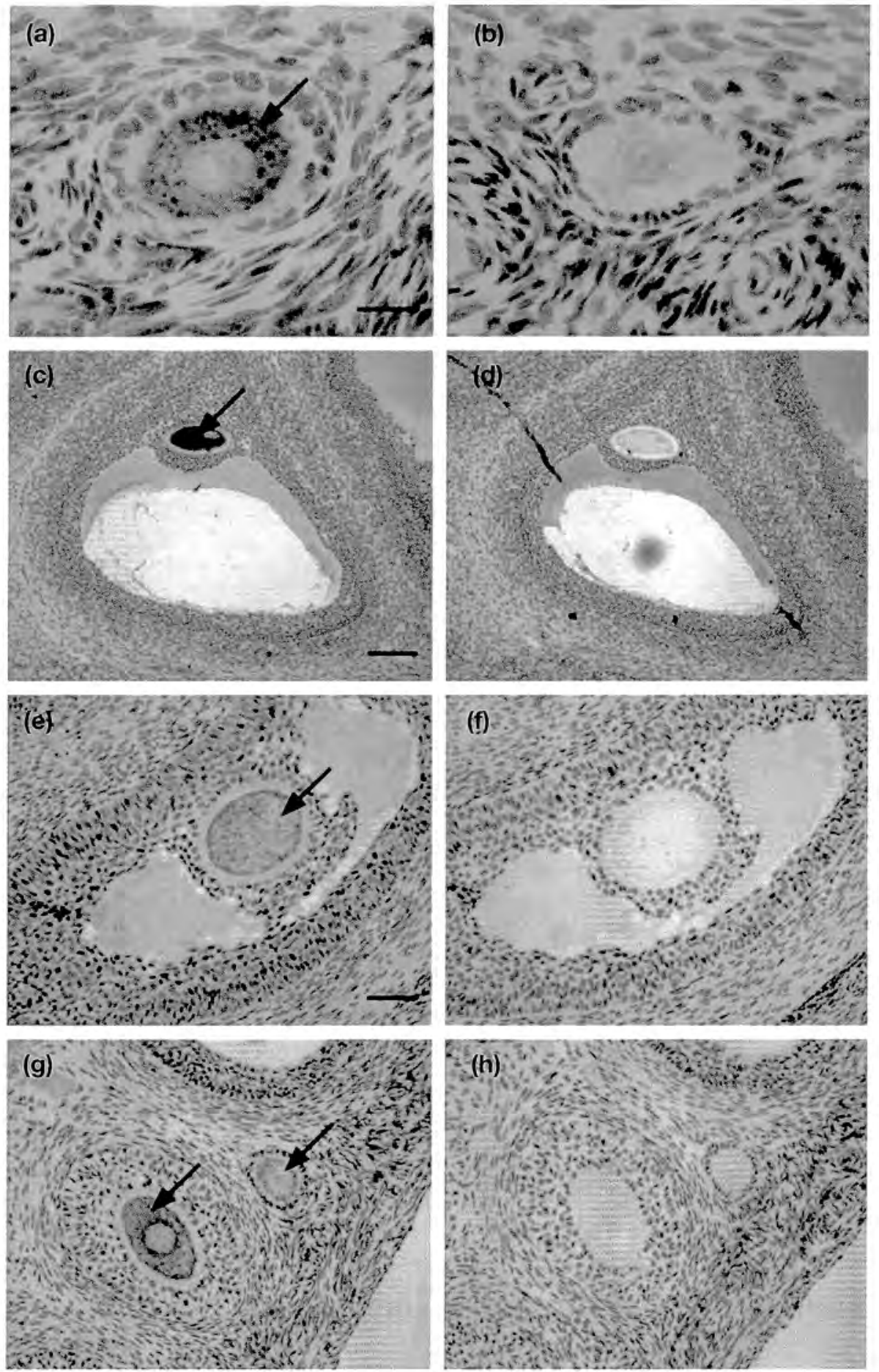

Fig. 1. Immunohistochemical evidence for the localization of growth differentiation factor 9 (GDF9) protein and bone morphogenetic protein 15 (BMP15) protein in oocytes (arrows) within developing ovarian follicles of 4-week-old ewe lambs. (a) GDF9 
a type 1 BMP receptor. The consequences are that females with one copy of this mutation have an ovulation rate of about one or two eggs more than the non-carriers and those with two copies have ovulation rates of about three to ten eggs more than non-carriers (McNatty et al., 2001; Davis et al., 2002). No major effects of the FecB ${ }^{B}$ mutation are evident in male sheep (Hochereau-de Reviers and Seck, 1991; Smith et al., 1996).

\section{BMP growth factors, BMP receptors and ovarian follicular development in sheep}

For the purposes of this review, the terminology described by Lundy et al. (1999) will be used to define the specific stages of ovarian follicular development in sheep, namely types 1, 1a, 2, 3, 4 and 5 for primordial, transitory, primary, small preantral, large preantral and antral follicles, respectively.

The mechanisms by which mutations in BMP15 or BMPR-IB influence ovulation rate in sheep are not well understood. Results from gene or protein expression studies in sheep ovaries show that BMP15, GDF9 and BMPR-IB are all expressed in oocytes (Fig. 1). However, whereas BMP15 and GDF9 are expressed exclusively in oocytes, BMPR-IB is expressed in oocytes, granulosa cells and luteal cells (Bodensteiner et al., 1999, 2000; Galloway et al., 2000; Wilson et al., 2001; Juengel et al., 2002; Souza et al., 2002). GDF9 mRNA and protein are expressed in most oocytes from the type 1 to type 1a stage of follicular development (Bodensteiner et al., 1999, 2000; Fig. 1) and BMP15 from the type 2 stage (Galloway et al., 2000; Fig. 1). Although both BMPR-IB and BMPR-II are expressed in oocytes and BMPR-II is expressed in granulosa cells from the type 1 stage, expression of BMPR-IB in granulosa cells is not evident until the type 2 stage of development (Wilson et al, 2001; Souza et al., 2002). Other TGF $\beta$ growth factors in sheep, such as $\beta_{B}$ inhibin-activin subunit or anti-Müllerian hormone and $\alpha$ inhibin-activin subunit, are expressed in granulosa cells from the type 2 and type 3 stages of growth, respectively (Montgomery et al., 2001).

In homozygous carriers of the Inverdale (II) and Hanna $(\mathrm{HH})$ mutations, normal ovarian follicular development is blocked from the type 2 stage of growth (Braw-Tal et al., 1993; Galloway et al., 2000). However, in II and $\mathrm{HH}$ ewes, oocytes can continue to grow from approximately $50 \mu \mathrm{m}$ in diameter in type 2 follicles to approximately $80-100 \mu \mathrm{m}$, which is typical of the diameter observed in type 4 or type 5 follicles without a concomitant increase in the number of granulosa cells (Braw-Tal et al., 1993; Galloway et al., 2000). These results imply that the oocyte is capable of growing independently of granulosa cells but that

Fig. 1. continued

localization in an oocyte of a type 2 (primary) follicle identified using a monoclonal antibody to GDF9 (Clone 37, $5 \mu \mathrm{g} \mathrm{ml}^{-1}$ ); (b) non-specific binding on an adjacent tissue section to (a) of an irrelevant polyclonal mouse antibody (that is, bovine $\alpha$ lactalbumin (M1-Lm, $\left.1.4 \mu \mathrm{g} \mathrm{ml}^{-1}\right)$ ); (c) GDF9 localization in an oocyte of a type 5 (antral) follicle identified using Clone 37 at $5 \mu \mathrm{g} \mathrm{ml}^{-1}$; (d) non-specific binding on an adjacent tissue section using an irrelevant monoclonal mouse antibody (YD3; $5 \mu \mathrm{g} \mathrm{ml}^{-1}$ ); (e) BMP15 localization in a type 5 follicle identified using affinity-purified polyclonal anti-BMP15 (M10$\left.9 \mathrm{~B}, 2 \mu \mathrm{g} \mathrm{ml} \mathrm{m}^{-1}\right)$; $(\mathrm{f})$ non-specific binding in an adjacent tissue section after preincubating M10-9B $(2 \mu \mathrm{g}$ $\left.\mathrm{ml}^{-1}\right)$ with an Escherichia coli generated oBMP15 mature protein $\left(10 \mu \mathrm{g} \mathrm{ml}^{-1}\right) ;(\mathrm{g})$ BMP15 localization in oocytes (arrows) of a type 2 and type 4 (large preantral) follicle identified using M10-9B $(2 \mu \mathrm{g} \mathrm{m})^{-1}$ ) antibodies; and (h) non-specific binding on an adjacent tissue section after preincubating M10-9B and oBMP15 mature protein. For experimental details see Juengel et al. (2002). Scale bars represent $(a, b)$ $20 \mu \mathrm{m},(\mathrm{c}, \mathrm{d}) 100 \mu \mathrm{m}$ and (e-h) $50 \mu \mathrm{m}$. 
oocyte-derived BMP15 is essential for the proliferation of granulosa cells for the advancement of follicles beyond the type 2 stage of growth.

Currently, there is uncertainty about the nature of molecular forms of BMP15 in biological fluids. It is thought that BMP15 and GDF9 function as homodimers or heterodimers, but until appropriate biologically active standards and highly specific antibodies become available, this question cannot be answered. However, it is known that GDF9 and BMP15 protein can be detected in oocytes and that the protein cannot be localized within any other type of ovarian cell (Fig. 1). Current evidence indicates that BMP15, in the absence of other TGF $\beta$ superfamily members, acts to stimulate DNA synthesis in granulosa cells of mammals with low and high ovulation rates. The addition of recombinant human BMP15 to oestrogenstimulated rat granulosa cells for $24 \mathrm{~h}$ (Otsuka et al., 2000) or a recombinant ovine BMP15 to ovine granulosa cells for $48 \mathrm{~h}$ (K. Reader, S. Lun, A. Western, S. Lawrence and K. P. McNatty, unpublished) stimulates a 2.0-2.5-fold increase in $\left[{ }^{3} \mathrm{H}\right]$ thymidine incorporation in vitro. In addition, Otsuka ef al. (2001) reported that recombinant BMP15 inhibits the biological actions of FSH by suppression of FSH receptor gene expression. They hypothesized from this finding that the higher ovulation rate in heterozygous Inverdale and Hanna ewes is due to a greater responsiveness of granulosa cells to a given amount of FSH because of a 'lowered dose' of oocyte-derived BMP15. The evidence from studies of granulosa cells in Inverdale ewes is that the onset of FSH receptor gene expression, which begins at the type 3 stage of follicle development, remains unchanged between the heterozygotes and non-carriers of the mutated BMP15 gene (Juengel et al., 2000). However, it is known that the FSH-induced CAMP responsiveness of granulosa cells from heterozygous Inverdale ewes in vitro is higher than in non-carriers and that granulosa cells from heterozygous animals acquire cAMP responsive $\mathrm{LH}$ receptors earlier in follicular development (Shackell et al, 1993). Whether this increased responsiveness to FSH in granulosa cells from Inverdale ewes is the result of an increased number of receptors or changes in the ability of the receptor to stimulate CAMP has not been determined.

Collectively, studies on Inverdale ewes heterozygous for an inactivating BMP15 mutation show that there are a greater number of smaller diameter antral follicles and that some of these follicles can undergo preovulatory maturation prematurely (that is, relative to wild-type ewes) and ovulate at a smaller follicular diameter (Shackell et al., 1993). The consequence of these changes is, on average, one more ovulation than in control sheep and the formation of smaller corpora lutea. The heterozygous Inverdale, and presumably Hanna, ewes are examples of sheep that have a higher ovulation rate than their littermate controls without any significant change in plasma FSH concentration. It is reasonable to hypothesize that the difference in ovulation rate in these genotypes is due entirely to a change in the intrafollicular concentrations of the oocyte-derived BMP15. Although in mice with heterozygous or homozygous inactivations of the BMP15 gene, there are no major effects on follicular development or ovulation rate, there is a modest reduction in litter size in knockout mice that is probably due to fertilization failure (Yan et al., 2001). These findings represent a fundamental difference between sheep and rodents.

The BMPR-IB mutation identified in Booroola and other breeds of sheep (Table 1 ) is a clear example of how a change in BMP signalling can lead to a significantly earlier maturation of differentiative functions in ovarian follicles. As a result, follicles become capable of ovulating after 16-17 doublings of the granulosa cell population instead of the normal 18-19 doublings observed in the wildtype (for a review, see Montgomery et al., 2001; Mulsant et al., 2001). Earlier maturation in follicles of Booroola ewes is evident by the type 3 stage of follicular development (Wilson et al., 2001). Moreover, from studies in hypophysectomized Booroola ewes, it is evident that follicles become gonadotrophin-dependent once they 
reach $2 \mathrm{~mm}$ in diameter, whereas in wild-type hypophysectomized Booroola ewes, follicles become gonadotrophin-dependent at about $3 \mathrm{~mm}$ in diameter, which is the equivalent of one granulosa cell doubling cycle later (McNatty et al, 1990). It remains unclear at present whether the earlier maturation process in follicles or the increased ovulation rate from the BMPR-IB mutation is driven by changes in oocyte regulation of granulosa cell function or through an interactive signalling exchange between these two types of cell. BMPR-IB mRNA has been identified in many tissues other than the ovary, such as brain, pituitary gland, skeletal muscle, testis, prostate gland and reproductive tract (Wilson et al., 2001). Thus, it is not surprising that the Booroola mutation has marked effects on organ development and on pituitary gland function (McNatty et al., 1995; Montgomery et al., 2001). Unlike the Inverdale and Hanna genotypes, in which all the major effects of the mutations are localized to the ovary, some effects in Booroola may be mediated via the pituitary gland as a result of higher than normal secretions of FSH (McNatty et al., 1991, 1993). At present, there is no equivalent mutation observed in mice or other high ovulation rate phenotypes with which to compare Booroola.

\section{Immunization of sheep against the oocyte-derived growth factors GDF9 and BMP15}

It has been suggested that some of the differences in the roles of BMP15 between rodents and sheep are due to species differences in the actions of GDF9 and BMP15: GDF9 is essential for follicular development in rodents and BMP15 is essential in sheep (Yan et al., 2001). However, this notion presupposes that GDF9 is ineffectual or less important in sheep.

The importance of GDF9 in sheep was tested by Juengel et al. (2002) who immunized ewes (9-10 per treatment group) with keyhole limpet haemocyanin (KLH) as a control, an ovine GDF9-specific peptide conjugated to KLH (GDF9 peptide) or an ovine BMP15 specific peptide conjugated to KLH (BMP15 peptide) at monthly intervals before and during the breeding season for 7 months. Ewes immunized with KLH maintained regular oestrous cycles (that is, $17 \pm 2$ days) during the breeding season. In contrast, none of the ewes immunized with GDF9 peptide experienced normal oestrous cycles of 17 days and most ewes (seven of ten) had no evidence of corpora lutea at the time the ovaries were recovered. Plasma concentrations of progesterone in the three ewes with corpora lutea were highly irregular and abnormal and not characteristic of a normal oestrous cycle. Many of the ewes without corpora lutea had no visible antral follicles at ovarian collection. Only one of ten of the ewes immunized with BMP15 peptide displayed regular oestrous cycles and this ewe had an average ovulation rate of six. In none of the other ewes immunized with BMP15 peptide was a corpus luteum visible on the surface of the ovary, and as with the GDF9 peptide-immunized group, many had no visible antral follicles at the time the ovaries were collected.

When the ovaries of these animals were examined histologically and subjected to morphometric analysis, it was evident that in both the GDF9 peptide and BMP15 peptide immunized groups, most ewes had few, if any, normal follicles beyond the type 2 stage of development. Of particular interest was the finding of numerous oocyte-free nodules of granulosa cells in both the GDF9- and BMP15-peptide immunized groups. These nodules were identical to those typically observed in homozygous Inverdale or Hanna ewes (Fig. 2) (Braw-Tal etal., 1993; Smith etal., 1997; Galloway et al., 2000). Although follicles beyond the type 2 stage of development were observed, these follicles often had unusually large oocytes relative to those in the control (that is, $\mathrm{KLH}$ treated) animals and the organization of the granulosa cells or the cumulus cells around the oocyte was abnormal (Fig. 2). These abnormal changes in morphology of the oocyte and granulosa cells in the GDF9-and 

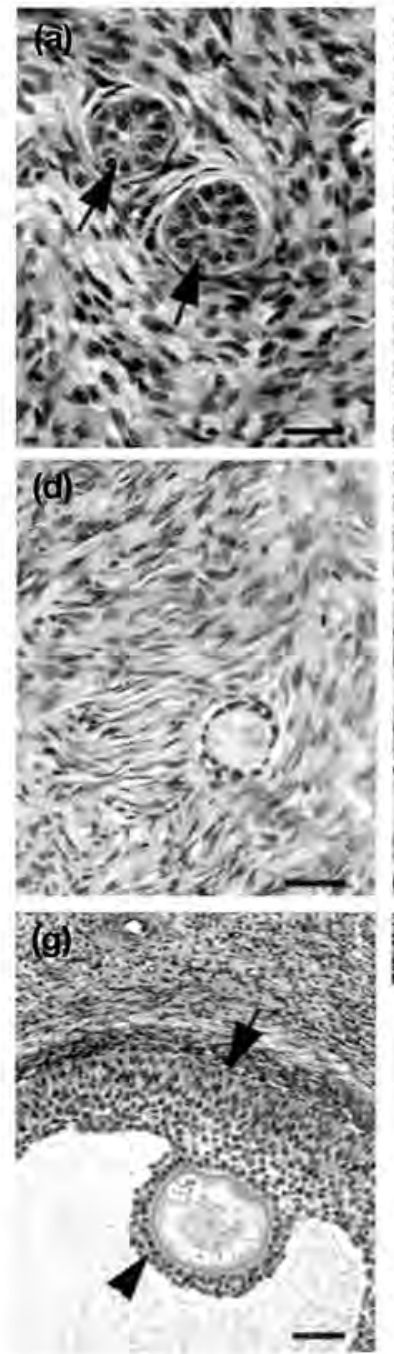
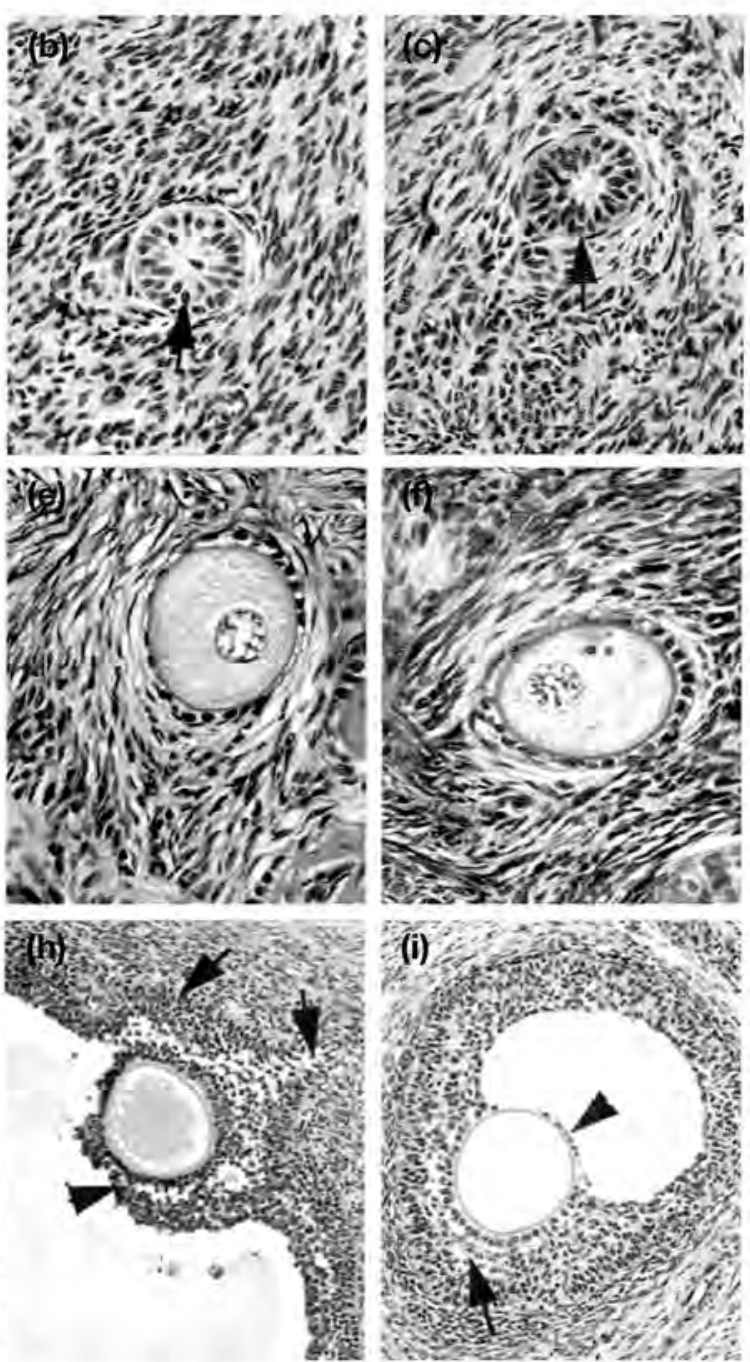
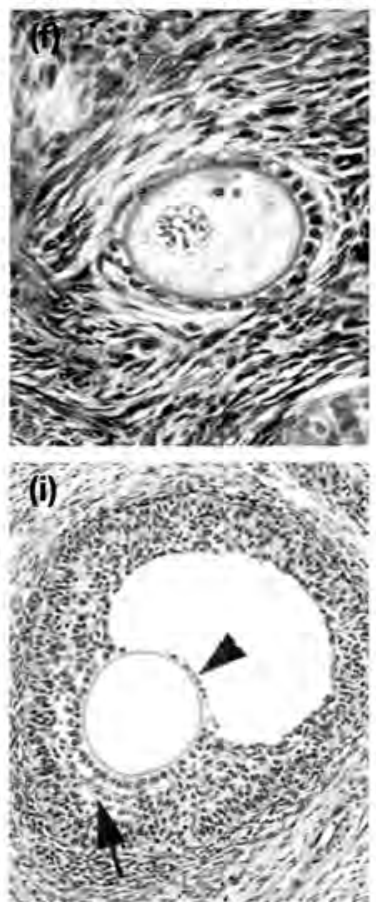

Fig. 2. Photomicrographs of sections through normal and abnormal follicles from carriers and non-carriers of the Inverdale gene or after long-term immunization with growth differentiation factor 9 (GDF9) or bone morphogenetic protein 15 (BMP15) peptide (Juengel et al., 2002). (a) Two oocyte-free follicles (arrows) in a ewe homozygous for the Fec $\mathrm{X}^{1}$ gene; (b) oocyte-free follicle (arrow) in a GDF9 peptide immunized ewe; (c) oocyte-free follicle (arrow) in a BMP15 peptide immunized ewe; (d) a type 1a (transitory) follicle in an Inverdale wild-type ewe; (e) an abnormal type 1 (primordial) follicle in an Inverdale ewe homozygous for the Fec $\mathrm{X}^{1}$ gene; (f) an abnormal type 1a follicle in a BMP15 peptide immunized ewe; (g) a normal antral follicle in an Inverdale wild-type ewe with a uniform distribution of cumulus cells around the oocyte (arrowhead) and an organized and uniform arrangement of granulosa cells around the basement membrane (arrow); (h) an antral follicle with abnormal appearance in a GDF9 peptide immunized ewe with a disorganized arrangement of cumulus cells (arrowhead) and also a disorganized array of granulosa cells around the basement membrane which appears highly irregular (arrows). (i) An abnormal-looking antral follicle in a BMP15 peptide immunized ewe with an abnormally enlarged oocyte, incomplete arrangement of cumulus cells (arrowhead) and extensive intercellular spaces (arrow) between cumulus cells. Scale bars represent $(\mathrm{a}-\mathrm{c}) 50 \mu \mathrm{m}$ and $(\mathrm{d}-\mathrm{i}) 30 \mu \mathrm{m}$. 
BMP15 peptide-immunized sheep were first evident at the type 1a and 2 stages of development (Fig. 2). Morphometric analysis revealed that the mean total numbers of types 4 and 5 follicles were significantly lower in the GDF9 peptide- and BMP15 peptide-immunized ewes compared with the KLH group, In the KLH-immunized ewes, the mean number of follicles $\geqslant 1 \mathrm{~mm}$ in diameter was ten, whereas in the GDF9 peptide and BMP15 peptide immunized groups, the mean numbers were two and < one, respectively. In these studies, evidence was found that the ewes immunized with the GDF9 peptide contained antibodies against Escherichia coli generated ovine (o)GDF9 protein but no crossreactivity (that is, <1\%) to E. coli generated oBMP15 protein. Likewise, ewes immunized with the BMP15 peptide contained antibodies against oBMP15 protein but not against oGDF9 protein (that is, $<1 \%$ ).

Collectively, these data indicate that GDF9, as well as BMP15, is essential for ovarian follicular development in sheep. Moreover, both growth factors are required very early in follicular development, namely from the type 1a and type 2 stage of development. These findings are in contrast to those in mice in which GDF9, but not BMP15, is required for the early stages of follicular development. After these observations, the question arose as to whether GDF9 and BMP15 are of any importance after follicles reach the antral stages of growth and become totally dependent on gonadotrophins for subsequent maturation and ovulation. Studies in rodents indicate that GDF9 is important for establishing the cumulus cell phenotype and that both GDF9 and BMP15 modulate the actions of FSH on differentiation of mural granulosa cells (Elvin et al., 1999; Erickson and Shimasaki, 2000; Vitt et al., 2000; Eppig, 2001; Otsuka et al., 2001). The importance of GDF9 and BMP15 in sheep was tested by giving each ewe (five per group) $100 \mathrm{ml}$ of a pool of antiplasma to GDF9 peptide, BMP15 peptide or KLH. The antiplasma for GDF9 or BMP15 peptide was collected from the aforementioned GDF9 or BMP15 immunized ewes that were anovulatory (Juengel et al., 2002). The antiplasmas were administered i.v. at day 4 before the induction of luteal regression or approximately 6-7 days before ovulation and all ewes were subjected to laparoscopy 8 days after the expected day of ovulation. The ewes that received the antiplasma against the GDF9 peptide formed one to two corpora lutea but three of five ewes did not display normal luteal phase patterns of progesterone concentrations. Four of the five ewes that received the antiplasma against BMP15 peptide failed to ovulate and the ovaries of three of five ewes were devoid of visible follicles. By contrast, ewes that were given $\mathrm{KLH}$ antiplasma ovulated with normal luteal function as assessed from the plasma progesterone concentrations. These data indicate that both GDF9 and BMP15 are important in regulating the later stages of follicular maturation as well as being essential for normal follicular growth.

From the long-term immunization studies, it was unclear whether partial neutralization of GDF9 was able to enhance ovulation rates (Juengel et al., 2002). This question was addressed in a preliminary study using a short-term immunization regimen with a weaker adjuvant than the Freund's complete or incomplete system used in the study by Juengel et al. (2002). It was hypothesized that a limited number of immunizations of ewes with GDF9 or BMP15 in a diethylaminoethyl dextran 5\% (w/v) PBS adjuvant would lead to a more modest antibody response and, thus, only a partial neutralization of GDF9 or BMP15. It was anticipated from such a treatment that some of the ewes immunized with BMP15 might have a higher than normal ovulation rate for BMP15-treated animals and the question as to whether GDF9 caused increases in ovulation rate might be resolved. Accordingly, ewes (eight per treatment group) were immunized on three occasions, at 1 month intervals, with KLH or KLH conjugated to GDF9 peptide (GDF9 peptide), BMP15 peptide (BMP15 peptide), oGDF9 protein (encoding the entire mature region) or oBMP15 protein (encoding the entire mature region). The ewes received $0.4 \mathrm{mg}$ antigen at the primary injection and $0.2 \mathrm{mg}$ boosters at the second and third injections. The ovaries of all ewes were examined by laparoscopy 14 days after the 
Table 2. Number of ewes with average ovulation rates of $0,1-3$ or $\geqslant 4$ after immunization with KLH or KLH conjugated to GDF-9 peptide, oGDF9 protein, BMP15 peptide or oBMP15 protein

\begin{tabular}{lccc}
\hline Treatment & 0 & $\begin{array}{c}\text { Mean ovulation rate } \\
1-3\end{array}$ & $\geqslant 4$ \\
\hline KLH & 0 & 8 & 0 \\
GDF9 peptide & 0 & 7 & 1 \\
oGDF9 protein & 3 & 1 & 4 \\
BMP15 peptide & 0 & 2 & 6 \\
oBMP15 protein & 1 & 4 & 3 \\
\hline
\end{tabular}

BMP: bone morphogenetic protein 15; GDF9: growth differentiation factor 9; KLH: keyhole limpet haemocyanin. H. Sawyer, C. Moeller, N. Hudson, I. luengel, K. McNatty, unpublished.

administration of the third injection when the ewes were also given a second prostaglandin $\mathrm{F}_{2 \alpha}$ injection ( 10 days after the first). In addition, the ovaries of all ewes were examined at slaughter at day 19 after laparoscopy. The range of ovulation rates recorded after first taking the average of the number of corpora lutea from the two successive ovulations for each ewe are shown (Table 2). Immunization of ewes with GDF9 peptide resulted in one ewe having an ovulation rate of 10 , which was the average of two successive ovulations of 12 and 8 . Immunization of ewes with the oGDF9 protein either resulted in most ewes having a higher than normal ovulation rate $(\geqslant 4)$ or anovulation. Treatment with either BMP15 peptide or oBMP protein led to $75 \%$ and $37.5 \%$ of ewes, respectively, having ovulation rates of $\geqslant 4$.

Examination of sera from ewes immunized against GDF9 peptide or protein revealed the presence of antibodies against oGDF9 protein, but no crossreactivity $(<2 \%)$ to $E$. coli generated oBMP15 protein. Likewise, ewes immunized with the BMP15 peptide or protein contained antibodies against oBMP15 protein, but not against oGDF9 protein $(<2 \%)$.

In all the aforementioned immunization studies particular attention was paid to whether ewes immunized with GDF9 had crossreactivities with the closely related BMP15 and vice versa. In no instance were measurable crossreactivities noted. As these proteins are much more closely related to each other than to other members of the TGF $\beta$ superfamily it is likely that the effects observed were specific for neutralization of the target protein.

These data indicate that GDF9 as well as BMP15 may enhance ovulation rate in sheep. Moreover, it appears that the dose of oocyte-derived GDF9 or BMP15 acting on the adjacent granulosa cells has profound effects on ovulation rate. These findings, taken together with the long-term immunization studies, support the hypothesis that in mammals with a low ovulation rate phenotype (for example, sheep), the oocyte has the ability to regulate both follicular development and ovulation rate through at least two different growth factors, GDF9 and BMP15.

\section{Conclusions}

From studies on sheep with unusual ovulation rates or fecundity, namely Booroola, Inverdale, Hanna, Garole and Javanese (Montgomery et al, 2001; Davis et al., 2001a,b; 2002), it is evident that there are now several major genetic mutations in sheep that lead to increased fecundity. In addition, it seems likely that several more fecundity-enhancing mutations will be identified in the future (for example, Woodlands: Davis et al., 2001b; for a review, see McNatty et al., 2001). When these genes and the mutations are identified, appropriate genetic marker tests can be developed (Davis et al., 2002). Collectively, these diagnostic tests have the potential to change farm management practices profoundly through rapid improvements in reproductive efficiency. 
The recent discoveries in sheep of the mutations in BMP15 and BMPR-IB together with recent results on the physiological effects of GDF9 and BMP15 on ovulation rate highlight some important differences in the way the oocyte may function in mammals with different ovulation rates. The evidence to date is consistent with the hypothesis that both follicular growth and ovulation rate are influenced by the dose of BMP15 or GDF9 delivered to the somatic cells of the follicle in mammals with a low ovulation rate phenotype, whereas in mammals with a high ovulation rate phenotype, the follicular somatic cells are relatively insensitive to changes in the dose of BMP15 but have an absolute requirement for GDF9.

This work was supported, in part, by a grant from the New Zealand Foundation for Research, Science and Technology (C10X0211) and the Marsden Fund (01-AGR-011, CMP) and by the USDA NRICGP99-2389 and the CSU Agricultural Experimental Station. O. Ritvos was supported by grants from the Academy of Finland, Sigrid Juselius Foundation and Helsinki University Central Hospital Funds. Part of the work by O. Ritvos and N. Groome was supported by grants from the European Commission. The authors wish to acknowledge L-A Still, L, O'Donovan, P. Smith, D. Heath, A. O'Connell, S. Lawrence and S. Lun for excellent technical assistance, and D. Jensen for his help with animal handling and management, and S. Swaney for secretarial assistance.

\section{References}

Baird DT and Campbell BK (1998) Follicle selection in sheep with breed differences in ovulation rate $\mathrm{Mo}$ lecular and Cellular Endocrinology $14589-95$

Bodensteiner KJ, Clay CM, Moeller CL and Sawyer HR (1999) Molecular cloning of the ovine growth/ differentiation factor-9 gene and expression of growth/differentiation factor-9 in ovine and bovine ovaries Biology of Reproduction 60 381-386

Bodensteiner KJ, McNatty KP, Clay CM, Moeller CL and Sawyer HR (2000) Expression of growth and differentiation factor-9 in the ovaries of fetal sheep homozygous for the Inverdale prolificacy gene Biology of Reproduction 62 1479-1485

Braw-Tal R, McNatty KP, Smith P, Heath DA, Hudson NL, Phillips DJ, McLeod BJ and Davis GH (1993) Ovaries of ewes homozygous for the X-linked Inverdale gene (Fec $X^{\prime}$ ) are devoid of secondary and tertiary follicles but contain many abnormal structures Biology of Reproduction 49 895-907

Davis GH, Montgomery GW, Allison AJ, Kelly RW and Bray AR (1982) Segregation of a major gene influencing fecundity in progeny of Booroola sheep New Zealand Journal of Agricultural Research 25 $525-529$

Davis GH, Bruce GD and Dodds KG (2001a) Ovulation rate and litter size of prolific Inverdale (FecX') and Hanna (Fec $\mathrm{X}^{\mathrm{H}}$ ) sheep Proceedings of the Association for Advanced Animal Breeding and Genetics $14145-178$

Davis GH, Dodds KG, Wheeler $\mathbf{R}$ and Jay NP (2001b) Evidence that an imprinted gene on the $\mathrm{X}$-chromosome increases ovulation rate in sheep Biology of Reproduction $64216-221$

Davis GH, Galloway SM, Ross IK et al. (2002) DNA tests in prolific sheep from eight countries provide new evidence on origin of the Booroola (FecB) mutation Biology of Reproduction 66 1869-1874
Dong J, Albertini D, Nishimori K, Kumar TR, Lu N and Matzuk MM (1996) Growth differentiation factor-9 is required during early ovarian folliculogenesis Nature $383531-535$

Driancourt MA, Philipon P, Locatelli A, Jaques E and Webb R (1988) Are differences in FSH concentrations involved in control of ovulation rate in Romanov and lle-de-France ewes Journal of Reproduction and Fertility 83 509-516

Elvin JA, Clark AT, Wang P, Wolfman NM and Matzuk MM (1999) Paracrine actions of growth differentiation factor-9 in ovarian function Molecular Endocrinology 15 854-866

Eppig J) (2001) Oocyte control of ovarian follicular development and function in mammals Reproduction $122829-838$

Erickson GF and Shimasaki S (2000) The role of the oocyte in folliculogenesis Trends in Endocrinology and Metabolism 11 193-198

Fry RC and Driancourt MA (1996) Relationships between follicle-stimulating hormone, follicle growth and ovulation rate in sheep Reproduction, Fertility and Development 8 279-286

Galloway SM, McNatty KP, Cambridge LM et al. (2000) Mutations in an oocyle-derived growth factor 15 (BMP15) cause increased ovulation rate and infertility in a dosage-sensitive manner Nature Genetics $25279-283$

Henderson KM, Savage LC, Ellen RL, Ball $K$ and McNatty KP (1.988) Consequences of increasing or decreasing plasma FSH concentrations during the preovulatory period in Romney ewes fournal of Reproduction and Fertility 84 187-196

Hochereau-de-Reviers MT and Seck M (1991) The male reproductive biology in prolific ovine breeds. In Major Genes for Reproduction in Sheep pp 177-196 Eds JM Elsen, L Bodin and J Thimonier. INRA, Paris 
Hudson NL, O'Connell AR, Shaw L, Clarke If and McNatty KP (1999) Effect of exogenous FSH on ovulation rate in homozygous carriers or non-carriers of the Booroola FecBa gene after hypothalamicpituitary disconnection or after treatment with a GnRH agonist Domestic Animal Endocrinology 16 69-90

Juengel JL, Quirke LD, Tisdall DJ, Smith P, Hudson NL and McNatty KP (2000) Gene expression in abnormal ovarian structures of ewes homozygous for the Inverdale prolificacy gene Biology of Reproduction $621467-1478$

Juengel JL, Hudson NL, Heath DA et al. (2002) Growth differentiation factor 9 and bone morphogenetic protein 15 are essential for ovarian follicular development in sheep Biology of Reproduction 671777 1789

Lundy T, Smith $\mathrm{P}, \mathrm{O}^{\prime}$ Connell $\mathrm{A}$, Hudson $\mathrm{NL}$ and McNatty KP (1999) Populations of small follicles in the sheep ovary Journal of Reproduction and Fertility $115251-262$

McNatty KP, Hudson NL, Gibb M, Ball K, Henderson KM, Heath DA, Lun S and Kieboom LE (1985) FSH influences follicle viability, oestradiol biosynthesis and ovulation rate in Romney ewes Journal of Reproduction and Fertility 75 121-131

McNatty KP, Hudson NL, Gibb M and Collins FL (1988) Plasma concentrations of $\mathrm{FSH}_{4} \mathrm{LH}$ and progesterone in sheep immunized against an androstenedioneprotein conjugate Journal of Reproduction and Fertility 82 63-69

McNatty KP, Heath DA, Hudson N and Clarke IJ (1990) Effect of long-term hypophysectomy on ovarian follicular populations and gonadotrophin-induced adenosine cyclic $3^{\prime}, 5^{\prime}$-monophosphate output by follicles from Booroola ewes with or without the F gene Journal of Reproduction and Fertility 90 515-522

McNatty KP, Hudson NL, Shaw L, Condell LA, Ball K, Seah S-L and Clarke If (1991) GnRH-induced gonadotrophin secretion in ovariectomized Booroola ewes with hypothalamic-pituitary disconnection Journal of Reproduction and Fertility 91 583-592

McNatty KP, Hudson NL, Lun S, Heath DA, Shaw L, Condell L, Phillips DJ and Clarke II (1993) Gonadotrophin-releasing hormone and the control of ovulation rate by the $\mathrm{Fec}^{\mathrm{B}}$ gene in Booroola ewes Journal of Reproduction and Fertility 98 97-105

McNatty KP, Smith P, Hudson NL, Heath DA, Tisdall DJ, O W-S and Braw-Tal R (1995) Development of the sheep ovary during fetal and early neonatal life and the effect of fecundity genes Journal of Reproduction and Fertility Supplement 49 123-135

McNatty KP, Heath DA, Lundy T, Fidler AE, Quirke L, O'Connell A, Smith P, Groome N and Tisdall DI (1999) Control of early follicular development Journal of Reproduction and Fertility Supplement $\mathbf{5 4}$ $3-16$
McNatty KP, Juengel JL, Wilson T, Galloway SM and Davis GH (2001) Genetic mutations influencing ovulation rate in sheep Reproduction, Fertility and Development 13 549-555

Montgomery GW, Galloway SM, Davis GH and McNatty KP (2001) Genes controlling ovulation rate in sheep Reproduction 121 843-852

Mulsant P, Lecerf F, Fabre S et al. (2001) Mutation in bone morphogenetic protein receptor-IB is associated with increased ovulation rate in Booroola ewes Proceedings National Academy of Sciences USA 98 $5104-5109$

Otsuka F, Yao Z, Lee T, Yamamoto S, Erickson G and Shimasaki S (2000) Bone morphogenetic protein 15 Journal of Biological Chemistry 275 39523-39528

Otsuka F, Yamamoto S, Erickson GF and Shimasaki S (2001) Bone morphogenetic protein-15 inhibits follicle-stimulating hormone (FSH) by suppressing FSH receptor expression Biological Chemistry 276 $11387-11392$

Scaramuzzi RJ, Adams NR, Baird DT et al. (1993) A model for follicle selection and the determination of ovulation rate in the ewe Reproduction, Fertility and Development 5 459-478

Shackell GH, Hudson NL, Heath DA, Lun S, Shaw L, Condell L, Blay LR and McNatty KP (1993) Plasma gonadotrophin concentrations and ovarian characteristics in inverdale ewes that are heterozygous for a major gene $\left(\mathrm{Fec} \mathrm{X}^{\top}\right)$ on the $\mathrm{X}$ chromosome that influences ovulation rate Biology of Reproduction $\mathbf{4 8}$ 1150-1156

Smith P, Hudson NL, Heath DA, Lun S, Shaw L, Condell L, Blay LR and McNatty KP (1996) Effects of the Booroola gene $\left(\mathrm{FecB}^{\mathrm{B}}\right)$ on body weight, testis development and hormone concentrations during fetal life Journal of Reproduction and Fertility $\mathbf{1 0 8}$ 253-261

Smith P, O W-S, Corrigan KA, Smith T, Lundy T, Davis GH and McNatty KP (1997) Qvarian morphology and endocrine characteristics of female sheep fetuses that are heterozygous or homozygous for the Inverdale prolificacy gene (Fec $X^{\dagger}$ ) Biology of Reproduction $571183-1192$

Souza CJH, MacDougall C, Campbell BK, McNeilly AS and Baird DT (2001) The Booroola (FecB) phenotype is associated with a mutation in the bone morphogenetic receptor type IB (BMPRIB) gene lournal of Endocrinology 169 R1-R6

Souza CJ, Campbell BK, McNeilly AS and Baird DT (2002) Effect of bone morphogenetic protein 2 (BMP2) on oestradiol and inhibin A production by sheep granulosa cells and localization of BMP receptors in the ovary by immunohistochemistry Reproduction $123363-369$

Vitt UA, Hayashi M, Klein C and Hsueh AJW (2000) Growth differentiation factor-9 stimulations proliferation but suppresses the follicle-stimulating hormone-induced differentiation of cultured 
granulosa cells from small antral and preovulatory rat follicles Biology of Reproduction 62 370-377

Wilson T, Wu X-Y, Juengel JL et al. (2001) Highly prolific Booroola sheep have a mutation in the intracellular kinase domain of bone morphogenetic protein IB receptor (ALK-6) that is expressed in both oocytes and granulosa cells Biology of Reproduction $\mathbf{6 4}$ 1225-1235

Yan C, Wang P, De Mayo J et al. (2001) Synergistic roles of bone morphogenetic protein 15 and growth differentiation factor 9 in ovarian function Molecular Endocrinology 15 854-866 